\title{
Risk Perception and Management in Smallholder Vegetable Farming in Eastern Ethiopia
}

\author{
Murad Ali Ahmed $^{1^{*}} \quad$ Jema Haji $^{2} \quad$ Belaineh Legesse $^{3} \quad$ Tinsae Demisse $^{4}$ \\ 1.School of Agricultural Economics and Agribusiness, Haramaya University, Tel: +251915766121 , P. O. Box: \\ 138, Haramaya University, Ethiopia \\ 2.School of Agricultural Economics and Agribusiness, Haramaya University, Ethiopia \\ 3.Director of research and Evaluation Division, Frontieri Consulting PLC, Addis Abeba, Ethiopia \\ 4.School of Agricultural Economics, Dilla University, Ethiopia
}

\begin{abstract}
This study examines vegetable producing farmers' risk perception and management strategies. Using survey data collected from 385 smallholder vegetable farmers from East Hararghe zone of Oromia region of Ethiopia, descriptive statistics and factor analysis were used for analyzing farmers risk attitude, classifying risk sources and management strategies. The analysis of risk attitude indicated that the majority of vegetable farmers considered themselves to be risk-takers towards important farm decisions which would help in the adoption of risk management strategies. The result of factor analysis identified low profitability, energy inaccessibility, production, price variability, human / social and institutional factors as principal sources of risk. Moreover, factor analysis also identified production management, loss minimizing and diversification as risk management strategies adopted by smallholder vegetable farmers. Policy makers should focus on enhancing the profitability of smallholder vegetable farmers, stabilizing input and output price, managing production risk, expanding energy access and facilitating the provision of necessary farm inputs. Moreover, it is also necessary to make the operation of cooperatives/unions accountable and their input provision fair and efficient.
\end{abstract}

Keywords: Vegetable farming, factor analysis, risk perception, risk management, risk attitude.

DOI: $10.7176 / \mathrm{JNSR} / 10-4-01$

Publication date: February $29^{\text {th }} 2020$

\section{Introduction}

Risk perception relates to the feeling and thoughts of human beings (Sjoberg, 1998). It includes the processing of information related to risk as well as the coping strategies used by people to deal with an uncertain outcome. Risk management is the measure undertaken by farmers anticipating the possibility of unfavorable event happening and taking appropriate action if the adverse event happens to minimize its impact (Kahan, 2008).

This study focused on the perception and management of risk of smallholder vegetable farmers in Eastern Ethiopia. Eastern Hararghe zone of Oromia in Eastern Ethiopia is well known for the production of different types of vegetables. The most commonly grown vegetables in terms of the number of growers are Irish potato, cabbage, onion, carrot, and beetroot (East Hararghe Zonal Agricultural Bureau, 2017). Vegetable marketing is also an important means of income generation and employment for farmers in the zone because it is well situated in terms of proximity to neighboring regions and countries.

The vegetables produced in Eastern Hararghe are marketed to nearby market centers like Kombolcha, Dire Dawa, Harar, Jigjiga and also exported to neighboring countries such as Djibouti and Somaliland. Even though vegetable production and marketing offer numerous opportunities as was previously stated, investment in the sector entails risk.

Several factors which are not within the control of farmers are responsible for the riskiness of vegetable production. The factors are related to biological plant growth, climatic condition, drought and floods (Chavas and Holt, 2002; Goodwin and Mishra, 2000). These factors cause random production shocks and harvest failure of vegetable production. Moreover, the riskiness of vegetable production could also be attributed to policy shocks (Dercon, 2002).

The perishability and unpredictability of yield create difficulty in scheduling the supply of vegetables to market demand. Moreover, vegetables are also affected by price and quantity risks coupled with changing consumer demand and production conditions. Unexpected weather condition or major crop diseases can also negatively influence the production and hence the marketing system.

Hence, it is important to examine the different types of risk faced by the smallholder vegetable farmers and risk management strategies they employ to mitigate the perceived risks. According to Harding (1998), 'risk refers to a combination of the probability, or frequency of occurrence of a defined hazard and the magnitude of the consequences of the occurrence.' In other words, it is concerned with the frequency of happening of the particular potentially harmful event and the consequence of this occurrence.

Studies related to risk perception and management has been conducted in both developed and developing countries. The studies related to risk in developed economies focused on a crop, livestock, aquaculture farmers 
perceptions of risk and management strategies (Ahsan and Roth, 2010; Akcaoz,H.,Kizilay,H.\& Ozcatalbas,O,2009; Flaten, M., Lien, G., Koesling, M., Valle, P.S., and Ebbesvik, M.; Koesling, M., Ebbesvik, M., Lien, G. , Flaten, O., Valle, P.S. and Arntzen, H., 2007). On the other hand, studies related to risk perception and management in developing economies focused on dairy farming, cereal, and legume production and general risk (Kinfe and Tewodros, 2013; Asravor, 2018; Belayneh and Drake, 2007). However, few studies focusing on risk perception and management with regard to vegetable farming has been conducted.

Some of the studies on risk perception in vegetable farming used a Likert scale to rank the various risk the farm households perceived (Kumilachew, A., Mengistu K., and Fekadu G., 2014). Other studies on vegetable farming risk perception and management dealt with the risk attitude and the factors influencing the farmers' risk attitude (Fakayode, 2012; Mehta, 2012). In this study, exploratory factor analysis was used to analyze risk perception and management strategies of vegetable farmers. The factor analysis was aimed at identifying the different sources of risk smallholder vegetable farmers faced and management strategies they utilized to mitigate the risk.

The remaining parts of the paper are organized as follows: the second section briefly describes the study areas and the data. Further, the section would also briefly discuss the statistical tools employed for the analysis. In section three, the results of the study are presented and discussed while the last section concludes.

\section{Materials and Methods}

\subsection{Description of the Study Areas}

The study was conducted in three woredas $^{l}$ (districts) of East Hararghe zone of Oromia region known for vegetable production and marketing. These woredas included Haramaya, Kombolcha, and Kersa. Oromia state is one of the constituent states of the Federal Democratic Republic of Ethiopia. The state borders Amhara and Afar regions in the northwest and northeast, Kenya in the south, Benishangul, Gambella and South Sudan in the west while bordering Somali regional state in the east. The region had an estimated population of over 35 million in 2017 (ethiovisit, 2019).

Haramaya Woreda

Haramaya is geographically situated between $42^{\circ} 3^{\prime} \mathrm{E}$ longitude and $9026^{\prime} \mathrm{N}$ latitudes with its altitude ranging from 1,400 to 2,340 meters above sea level (masl). It is bordered by Kurfachale in the south, by Kersa to the west, to the north by Dire Dawa, to the east by Kombolcha, and by the Harari Region to the southeast (Nigussie. D., Haile, D., Wole, K., Tamiru, A., Olkeba, B., Samuel, T., Solomon, A. and Mengistu, K. ,2014). The district has a projected total population of 359,243 based on the 2007 census.

\section{Kombolcha Woreda}

Kombolcha is one of eighteen districts in East Haraghe Zone of Oromia. The district is located about 514 kilometers $(\mathrm{km})$ away from the capital of the country and $14 \mathrm{~km}$ northwest of Harar town. The altitude of the district ranges between 1,600-2,400 meter above sea level (masl). The woreda is bordered to the west by Haramaya woreda, to the south by Harari Regional State, to the east by Jarso woreda and to the north by Dire Dawa City Administration (Nigussie et al., 2014). The total projected population of Kombolcha woreda based on data obtained from the report of the 2007 Population and Housing Census in Ethiopia is 170,151.

\section{Kersa Woreda}

Kersa is among the woredas found in East Hararghe zone of Oromia National Regional State. The woreda is bordered on the southeast by Kurfachele woreda, on the northeast by Haramaya woreda, on the north by Dire Dawa administrative council, on the west by Meta woreda and on the south by Bedeno woreda (Nigussie et al., 2014). Moreover, the woreda's capital is Kersa, which is $44 \mathrm{~km}$ from Harar westwards. The altitude of woreda ranges from 1400 to 3200 meters above sea level. Based on the 2007 census, the woreda has a total projected population of 262,106 .

\footnotetext{
${ }^{1}$ Woreda is an administrative unit equivalent to a district.
} 
Table 1. Socioeconomic and demographic characteristics of vegetable farmers

\begin{tabular}{|c|c|c|c|c|}
\hline Items & Haramaya & Kombolcha & Kersa & Overall \\
\hline Age & $44.95(8.62)$ & $40.36(6.29)$ & $43.84(10.94)$ & $43.05(8.62)$ \\
\hline \multicolumn{5}{|l|}{ Sex } \\
\hline Male & $132(42.17)$ & $82(26.19)$ & $99(31.63)$ & 313 \\
\hline Female & $29(40.28)$ & $14(19.44)$ & $29(40.28)$ & 72 \\
\hline \multicolumn{5}{|l|}{ Non-farm activities } \\
\hline Yes & $98(34.03)$ & $78(27.08)$ & $112(38.89)$ & 288 \\
\hline No & $63(64.95)$ & $18(18.56)$ & $16(16.49)$ & 97 \\
\hline \multicolumn{5}{|l|}{ Main occupation } \\
\hline Yes & $118(38.31)$ & $85(27.59 \%)$ & $105(34.09 \%)$ & 308 \\
\hline No & $43(55.84)$ & $11(14.29 \%)$ & $23(29.87 \%)$ & 77 \\
\hline \multicolumn{5}{|l|}{ Marital status } \\
\hline Married & $124(40.66)$ & $81(26.56)$ & $100(32.79)$ & 305 \\
\hline Not married & $37(46.25)$ & $15(18.75)$ & $28(35)$ & 80 \\
\hline Education (years) & $4.25(3.59)$ & $3.97(3.27)$ & $4.41(3.84)$ & $4.21(3.57)$ \\
\hline Household size & $7.27(2.75)$ & $6.5(2.43)$ & $6.25(2.49)$ & $6.67(2.56)$ \\
\hline Vegetable Experience & $25.99(10.68)$ & $19.95(8.68)$ & $23.52(18.79)$ & $23.15(12.72)$ \\
\hline Time taken to main market & $97.79(25.97)$ & $88.76(27.7)$ & $134.39(20.34)$ & $106.98(24.67)$ \\
\hline Farm income in birr & $\begin{array}{l}79,861.4 \\
(39101)\end{array}$ & $\begin{array}{l}70,404.1 \\
(65527.21)\end{array}$ & $\begin{array}{l}38,453.53 \\
(31327.85)\end{array}$ & $\begin{array}{l}62,906.39 \\
(45318.69)\end{array}$ \\
\hline Livestock income in birr & $\begin{array}{l}6870.93 \\
(13037.32)\end{array}$ & $\begin{array}{l}34646 \\
(296649)\end{array}$ & $\begin{array}{l}2178.75 \\
(4750.38)\end{array}$ & $\begin{array}{l}43698.76(104812 . \\
23)\end{array}$ \\
\hline Farm size (ha) & $0.39(0.5)$ & $0.41(0.18)$ & $0.4(0.22)$ & $0.4(0.3)$ \\
\hline $\begin{array}{l}\text { Proportion of land under } \\
\text { vegetable(ha) }\end{array}$ & $0.203(0.105)$ & $0.19(0.095)$ & $0.24(0.17)$ & $0.211(0.123)$ \\
\hline
\end{tabular}

Source: own survey, 2018.

Note: Figures presented for the categorical variable are number (\%) and mean (SD) for continuous variables

\subsubsection{Data}

The research involved interviews with sampled smallholder farmers from Eastern Hararghe zone of Ethiopia. The choice of the zone is because the zone is among the very well-known zones in vegetable production and marketing. Moreover, the zone is also characterized by climatic risk, high population density, unconducive and fragmented agricultural land and unpredictable rainfall (Nigusie and Jeylan, 2018).

The sampling method used was multistage sampling techniques to select 385 smallholder vegetable farmers from 3 woredas and 12 kebeles $^{l}$. The first stage involved purposely selecting the potential vegetable producing zones in eastern Ethiopia. The second stage involved the selection of three woredas among the potential vegetable producing woredas. The selection of potential vegetable producing kebeles among the sampled woredas took place in the third stage while the selection of 385 sample rural households from the selected kebeles constituted the fourth stage.

\subsubsection{Statistical Methods}

Farmers' perception of sources of risk, risk management strategies were analyzed using factor analysis while risk attitude was analyzed through aggregation in the smallholder vegetable production system. Factor analysis reduces the larger number of variables into smaller dimensions.

Factor analysis is a multivariate technique used to examine the variability of variables in a data set (in our case, risk sources and management strategy variables) through a linear combination of a smaller number of latent variables, called factors. Eigenvalues indicate the extent of variation between variables in each factor. If variables have a strong relationship, a significant proportion of the total variance is explained by the first few factors and the last factors explain little additional information. In this study, factors with eigenvalues greater than one were retained.

To reconstruct the scores on the original variables of factor analysis, the oblique rotation was used for linear functions of correlated factors for risk perception and risk management strategies. The Cronbach alpha was calculated to check the internal reliabilities of constructs. The Cronbach alpha values of 0.7 or higher is regarded "acceptable" in researches conducted in the social science (Hair, 2006).

The KMO (Kaiser-Meyer-Olkin) test gives a qualitative index indicating the strength of relationship among variables based on zero-order and partial correlations. The value of KMO is between 0 and 1 with higher numbers representing greater adequacy (Watson, 2017). For interpreting the retained factors, variables with factor loadings

\footnotetext{
${ }^{1}$ Kebele is the smallest administrative unit equivalent to a ward.
} 
greater than 0.45 for risk perception and 0.5 for risk management strategy were used, which is considered satisfactory (Flaten et al., 2005). The higher load is more important in defining factors dimensionality. The highness of the load implies the degree of communality (relation) that each item has with the rest of the items of risk perception and management strategy. In this study, at least three variables (items) with significant loadings are considered in each retained factor (see also Asravor, 2018).

\section{Results and Discussion}

Smallholder vegetable farmers' relative risk attitude were analyzed to rate their willingness to take production, marketing, human/personal, institutional and finance-related risks relative to other farmers in their woreda on a Likert-type scale. The scale ranged from one (much less willing) to five (much more willing). The results from Table 2 show that respondents from category 1 and 2 perceive themselves as partly less willing and much less willing to take the risk; category 4 and 5 considered themselves as more willing and much more willing to take the risk and category 3 as partly willing.

About 71,71, 62, 60 and $67 \%$ of smallholder vegetable farmers regarded themselves relatively as at least partly willing to take production, marketing, human/personal, institutional and finance-related risks, respectively. This indicated that a significant proportion of the vegetable farmers regarded themselves as risk-takers.

Table 2. Relative risk aversion by vegetable farmers

\begin{tabular}{llllll}
\hline & \multicolumn{5}{l}{ Relative risk aversion ${ }^{1}(\%)$} \\
\hline Risk category & 1 & 2 & 3 & 4 & 5 \\
\hline Production & 8.57 & 20.52 & 37.4 & 19.74 & 13.77 \\
Marketing & 14.03 & 15.06 & 35.06 & 25.45 & 10.39 \\
Human/personal & 14.03 & 22.59 & 25.45 & 21.56 & 15.32 \\
Institutional & 14.55 & 25.97 & 42.34 & 13.25 & 3.89 \\
Finance & 9.09 & 23.64 & 35.32 & 15.32 & 16.62 \\
\hline
\end{tabular}

Source: own computation

Production risk-taking decision is related to farmers' decision to prevent or minimize the impact of pest disease, plant disease and of the unpredictable weather condition. Marketing risk-taking decision is linked to the farmers' decision with regard to market accessibility, perishability of produce, input and output price fluctuation and transport cost. On the other hand, personal risk-taking decision is associated with the farmers' decision regarding the shortage of labour, the health of the family members and conflict and violence within the family. Financial risks are associated with the farmers' decision regarding the use of credit to finance farm investment.

Institutional risks are associated with the farmers' decision with regard to facing constraints of poor and inefficient service delivery by both cooperatives and government agencies. Thus, from the aforementioned discussion, it could be deduced that a good proportion of vegetable farmers considered themselves as risk-takers in relation to the decision they take with regard to production, marketing, finance, human/personal and institutional related risks. Some attribute the farmers' risk-taking attitude to the expansion of farmer field schools and extension services that resulted in awareness creation (Knife and Tewodros, 2013).

\subsection{Smallholder vegetable farmers' perception of various sources of risk}

Overall, 25 risk sources were identified in the smallholder vegetable farming based on theory, empirical studies and personal experience of the study areas. A factor analysis on risk sources has been conducted with the principal axis factoring followed by oblique rotation as the factors have a correlation. From the factor analysis, the total variance accounted for risk sources was observed to be 48.57 while the cronbach alpha value was 0.789 for risk sources which is acceptable (Hair, 2006). The measures of sampling adequacy of Kaiser-Meyer-Olkin for sources of risk gave a value of 0.797 .

This KMO value implies the variables overall have $79.7 \%$ in common to justify a factor analysis. The factor analysis identified six factors with eigenvalues greater than 1 (see Table 3 and Fig. A.1 in the Appendix 1). Factors 1 to 6 were identified as low profitability, energy inaccessibility, production, price variability, human / social and institutional.

A low profitability risk on factor 1 is associated with lack of profitability, high price of fertilizer, high price of farm equipment, difficulty of accessing market information and high fuel cost. The rising cost of inputs has implications for the profitability of the vegetable farming enterprise. The variability of the price of feed was considered as one of the vital risk sources in shrimp farming in Bangladesh (Ahsan, 2011). Norwegian farmers also considered price of feed as one of the major sources risk (Bergfjord, 2009). Sources of risk related with rising cost of fuel has also been perceived as significant source of risk in the production of vegetables in eastern Ethiopia

\footnotetext{
${ }^{1}$ Relative risk: $1=$ much less willing $2=$ less willing 3=Partly willing 4=More willing 5=Much more willing

${ }^{2}$ In order to elicit risk attitude, vegetable farming households were asked the following question: "Are you more willing than others to take risk related to (each risk category)'
} 
(Emana and Gebremedhin, 2007). The high cost of fuel translates into a high cost of production which decreases the profit margin of smallholder farmers. Similarly, a study by Ali and Kapoor (2008) in India also showed that farmers regarded the rising cost of fuel as one the most significant sources of risk that have an impact on profitability.

Energy risk on factor 2 is associated with access to electricity and the constant power blackout affecting the operation of farm activities. Agriculture requires energy as one of an important input to production. The sector also uses energy directly as fuel or electricity to run machinery and equipment (Schnepf, 2004). As farmers stated, using electricity for power generators has a significant cost advantage over using fuel for power generation. However, the supply of electricity is beset with constant power blackout. From the informal discussion, it was also learned that those farmers who have access to electricity face a constant power blackout. On the other hand, those who lack access to electricity use fuel to pump water for irrigation.

Production risk on factor 3 had high loadings of pest disease and termite attack. Crop pests can be broadly grouped as above ground and below ground pest. Otieno (2018) stated that pest attack together with disease occurrences accounted for about $49 \%$ of crop yield losses recorded in Africa which is considered the highest loss globally. Among below ground pests, termites are causing significant crop yield losses. For instance, termites were responsible for the loss in maize yield in affected fields accounting for more than $50 \%$ in Nigeria and Ethiopia while losses of 10-30\% were reported in Kenya, Uganda, and Tanzania (Maniania, 2002; Sekamatte, 2003).

In the case of eastern Ethiopia, pests can considerably affect crop yields causing farmers to lose interest in its cultivation (Emana and Gebremedhin, 2007). It was also further noted that aphids, bollworm, leaf eaters, thirps, fruit flies, powdery mildew and blights on fruits and vegetables are concerns for farmers in Dire Dawa, Kersa, Kombolcha, Haramaya, Chiro, Gamachis and Harari. Similarly, shrimp disease has also been identified as the top rated source of risk in the study conducted on shrimp farmers risk perception in Bangladesh (Ahsan, 2011). Similar findings were also confirmed in the emerging mussel aquaculture industry in Denmark. The study indicated that bad weather, harmful algal blooms (HABs), oxygen depletion and E. coli were considered as significant risks to production (Ahsan and Roth, 2010).

The results of risk analysis in Nigeria on vegetable and fruits indicated that damage by pest and disease was among the top rated sources of risk (Fakayode, Rahji and Adenyi, 2012). The problem of pest and diseases also highly affected rice farming in Thailand (Addito, Gan and Nartia , 2010). Similarly, the study examining the perception of risk and management strategies in onion production in Nigeria discovered drought and pest/disease as among the important risks affecting the production of onion (Alimi and Ayalwale, 2005). On the other hand, crop farmers in Norway and sugarcane farmers in South Africa considered price and yield variability as very important (Koesling et al., 2004; Nicol and Ortmann, 2010).

Unexpected variability of output and input price loaded strongly on factor 4 . This could be correlated with the availability of inputs like fertilizer and improved seed and other pertinent inputs. Price variability could be also be caused by a lack of market access for the vegetable produce. The results found by Alamerew (2013) also showed that farmers ranked output price fluctuation as the most significant market risk followed by the rising cost of inputs in the case of Kombolcha woreda of eastern Ethiopia.

A study examining the risk perception and management of rice farmers in Thailand indicated that unexpected variability of input prices as the significant source of risk. The variability affected the price of chemical fertilizers, wage rates of hired labor and the land rental rates. Nicol and Ortman (2010) indicated that crop price variability and the change of legislation regarding minimum wage were important sources of risk for large scale sugar cane farmers. Similarly, the future mussel demand and the future mussel prices were the highly ranked risk sources for mussel aquaculture industry in Denmark.

Smallholder vegetable farmers are also affected by risks associated with human risk. Human risk of factor 5 highly loaded on variables such as family labor availability and family conflict and violence. The results related to human risk is consistent with other studies (Meuwissen, Huirne and Hardaker, 2001; Flaten et al., 2005). Smallholder vegetable farmers have great concern regarding the availability of family labor that would take care of activities such as preparing, planting, watering, applying different inputs, harvesting and marketing the produce. Hence, human risks associated with inadequate family labor and conflict among family members represent challenges for the development of smallholder vegetable farming.

In the study by Nicol and Ortmann (2010), the threat of HIV AIDS was very important for large scale sugarcane farmers in South Africa. Moreover, the illness or death of the farm operator and the changing of family relationship is also considered as an important source of risk by large scale sugarcane farmers. The study by Ahsan and Roth (2010) on perceived risk source and risk management strategy in an emerging mussel aquaculture industry in Denmark found that risk of injury to farmers and their employees represented an important source of human risk.

The issue of human risk also featured prominently in the study by Alimi and Ayanwale (2005) on risk and risk management strategies in onion production in Nigeria. They discovered that ill health, death and unavailability of labor as an important source of risk. Likewise, a study by Alamerie et al. (2014) found human risk to be 
important in vegetable farming in Kombolcha woreda. Hence, it was discovered that illness/injury and death of the farm operator were found to be the top ranked sources of human risk.

The lack of government support and the lack of fair distribution of inputs by the cooperative loaded strongly on factor 6 of the institutional risk. Informal discussion with farmers indicated that farmers complained that the government support related with agricultural extension, dissemination of modern inputs, training of farmers in applying modern technics was limited. Moreover, the complaints of farmers was also related with the provision of inputs by the cooperative. They stated that the inputs are given to them at a higher price than the perceived subsidized price the cooperatives/unions were supposed to deliver.

Institutional risk also features in other studies related with crop farming, dairy farming and shrimp farming. Both conventional and organic group crop farmers in Norway assigned more importance for institutional sources of risk related with the farm support payment by government. The result from the risk perception of rice farmers in Thailand also indicated the importance of institutional risk. The risk perceived was related with changes in Thailand's economic and political situation and changes in national governmental laws and policies that would affect the farming sector. A study by Flatten et al. (2005) indicated the importance of institutional risk in dairy farming. Credit availability was considered the prominent source of institutional risk in the case of shrimp farming in Bangladesh (Ahsan, 2011). The problem of managing untrustworthy employee, supply of private capital and the increasing protest and repugnance to shrimp farming represented important sources of institutional risk in Bangladesh (Ahsan, 2011).

Table 3. Average score and oblimin rotated factor loading for risk sources

\begin{tabular}{|c|c|c|c|c|c|c|c|c|c|}
\hline & Sample & & & Factor & & & & & \\
\hline Sources of risk & Communality & Mean & SD & 1 & 2 & 3 & 4 & 5 & 6 \\
\hline Pests & 0.551 & 3.961 & 1.041 & -0.045 & -0.043 & 0.618 & 0.228 & -0.227 & 0.168 \\
\hline $\begin{array}{l}\text { Termites/insect } \\
\text { attack }\end{array}$ & 0.376 & 3.953 & 1.032 & 0.286 & -0.047 & 0.508 & 0.139 & -0.288 & 0.101 \\
\hline $\begin{array}{ll}\text { Soil } & \text { fertility } \\
\text { decline } & \end{array}$ & 0.567 & 3.919 & 1.202 & -0.063 & 0.156 & -0.011 & 0.103 & 0.48 & 0.078 \\
\hline $\begin{array}{l}\text { Lack of } \\
\text { discriminating } \\
\text { pricing systems }\end{array}$ & 0.417 & 3.859 & 1.099 & 0.202 & -0.183 & -0.077 & -0.17 & 0.19 & -0.299 \\
\hline $\begin{array}{l}\text { Shortage of } \\
\text { irrigation water }\end{array}$ & 0.525 & 3.748 & 1.271 & 0.11 & 0.255 & 0.241 & -0.102 & 0.419 & -0.244 \\
\hline $\begin{array}{ll}\text { Volatility } & \text { of } \\
\text { product price }\end{array}$ & 0.421 & 3.729 & 0.968 & 0.086 & -0.099 & 0.023 & 0.635 & 0.122 & -0.092 \\
\hline $\begin{array}{ll}\text { Lack } & \text { of } \\
\text { profitability } & \text { of } \\
\text { vegetables } & \\
\end{array}$ & 0.574 & 3.709 & 1.084 & 0.794 & -0.127 & -0.052 & 0.057 & 0.004 & -0.137 \\
\hline $\begin{array}{l}\text { Lack of } \\
\text { coordination } \\
\text { among producers }\end{array}$ & 0.239 & 3.704 & 0.977 & -0.086 & -0.424 & 0.081 & 0.108 & 0.012 & 0.103 \\
\hline $\begin{array}{l}\text { Exploitation by } \\
\text { middle men }\end{array}$ & 0.362 & 3.657 & 1.142 & 0.015 & -0.11 & 0.354 & -0.064 & 0.248 & 0.015 \\
\hline $\begin{array}{l}\text { High price of } \\
\text { fertilizer }\end{array}$ & 0.652 & 3.602 & 1.267 & 0.644 & -0.073 & -0.017 & 0.071 & 0.067 & 0.302 \\
\hline $\begin{array}{l}\text { High price of farm } \\
\text { equipment }\end{array}$ & 0.288 & 3.579 & 0.965 & 0.541 & 0.062 & 0.063 & 0.241 & 0.207 & -0.091 \\
\hline $\begin{array}{lr}\text { Lack of fair } \\
\text { distribution } & \text { of } \\
\text { inputs by } & \text { the } \\
\text { cooperative } & \end{array}$ & 0.448 & 3.561 & 1.109 & -0.141 & -0.028 & 0.182 & -0.102 & 0.419 & 0.445 \\
\hline $\begin{array}{l}\text { Volatility of input } \\
\text { prices }\end{array}$ & 0.323 & 3.558 & 1.004 & 0.009 & 0.11 & 0.043 & 0.551 & 0.019 & 0.095 \\
\hline Transport cost & 0.448 & 3.538 & 1.141 & 0.186 & 0.225 & 0.294 & -0.333 & 0.216 & 0.08 \\
\hline $\begin{array}{l}\text { Inadequate family } \\
\text { labour }\end{array}$ & 0.526 & 3.538 & 1.148 & -0.063 & 0.053 & 0.067 & 0.097 & 0.697 & 0.075 \\
\hline $\begin{array}{l}\text { Difficulty } r \\
\text { accessing market } \\
\text { information }\end{array}$ & 0.47 & 3.525 & 1.25 & 0.699 & -0.028 & 0.004 & -0.039 & -0.084 & -0.028 \\
\hline
\end{tabular}




\begin{tabular}{|l|l|l|l|l|l|l|l|l|l|}
\hline \multicolumn{2}{|l|}{ Sample } & \multicolumn{2}{l}{ Factors } \\
\hline Sources of risk & Communality & Mean & SD & $\mathbf{1}$ & $\mathbf{2}$ & $\mathbf{3}$ & $\mathbf{4}$ & $\mathbf{5}$ & $\mathbf{6}$ \\
\hline $\begin{array}{l}\text { Production cost } \\
\text { variability }\end{array}$ & 0.497 & 3.426 & 1.182 & 0.393 & 0.277 & -0.083 & 0.085 & -0.182 & 0.288 \\
\hline High cost of fuel & 0.549 & 3.426 & 1.401 & 0.572 & -0.008 & 0.196 & -0.024 & -0.094 & 0.222 \\
\hline $\begin{array}{l}\text { Lack of } \\
\text { government } \\
\text { support } \\
\text { providing inputs }\end{array}$ & 0.497 & 3.423 & 1.242 & 0.177 & -0.234 & 0.084 & -0.014 & -0.084 & 0.504 \\
$\begin{array}{l}\text { Perishability of } \\
\text { produce }\end{array}$ & 0.603 & 3.405 & 1.288 & -0.088 & 0.406 & 0.276 & -0.248 & 0.34 & -0.112 \\
\hline $\begin{array}{l}\text { Family conflict } \\
\text { and violence }\end{array}$ & 0.524 & 3.278 & 1.484 & 0.333 & 0.164 & 0.184 & -0.155 & 0.69 & 0.206 \\
\hline $\begin{array}{l}\text { Unavailability of } \\
\text { capital }\end{array}$ & 0.441 & 3.273 & 1.271 & 0.432 & -0.039 & 0.103 & -0.186 & 0.1 & 0.293 \\
\hline $\begin{array}{l}\text { Lack of access to } \\
\text { electricity }\end{array}$ & 0.796 & 3.151 & 1.725 & -0.065 & 0.846 & 0.014 & 0.046 & 0.074 & -0.066 \\
\hline $\begin{array}{l}\text { Constant power } \\
\text { blackout }\end{array}$ & 0.865 & 3.005 & 1.672 & -0.123 & 0.896 & -0.066 & 0.133 & 0.101 & 0.049 \\
\hline $\begin{array}{l}\text { High burden of } \\
\text { debt }\end{array}$ & 0.284 & 2.956 & 1.219 & 0.371 & 0.113 & 0.214 & -0.036 & 0.156 & -0.07 \\
\hline $\begin{array}{l}\text { Percent of total } \\
\text { variance } \\
\text { explained }\end{array}$ & - & - & - & 17.421 & 16.084 & 5.038 & 4.792 & 3.06 & 2.569 \\
\hline $\begin{array}{l}\text { Cumulative } \\
\text { percent of the } \\
\text { variance } \\
\text { explained }\end{array}$ & & & & 17.421 & 33.506 & 38.544 & 43.336 & 46.396 & 48.965 \\
\hline
\end{tabular}

Source: own computation

\subsection{Smallholder Vegetable Farmers' Risk Management Strategies}

For the risk management strategies, 25 items were considered in the smallholder vegetable farming system based on theory and empirical studies. A factor analysis on risk management strategies has been conducted with principal axis factoring followed by oblique rotation as the factors have a correlation. The total variance accounted for risk management strategies was observed to be 54.81(see Table 4). The Cronbach alpha was calculated for risk management strategies to examine the internal reliabilities. The result is 0.94 , which is considered acceptable (Hair, 2006).

The KMO (Kaiser-Meyer-Olkin) value for risk management strategies was found to be 0.935 . Thus the KMO (Kaiser-Meyer-Olkin) value indicate the adequacy of the items for factor analysis due to a large portion of communality. The result further identified three factors with eigenvalues greater than 1 .

The three risk management strategies were production, loss minimizing and diversification strategies (see Fig. $\mathrm{b}$ in Appendix 1). Factor 1 included use of fertilizers, improved seed variety, using irrigation, having a farm reservoir and increasing labor for agricultural activity, using development agent advice and applying insecticide. These risk management strategies are used by farmers to control production-related risk in the study area. Similarly, rice-producing farmers in Thailand accorded more importance to production and financial strategies than marketing strategies (Aditto, 2012).

The strategy of preventing or reducing crop disease and pests were also adopted in the case of both conventional and organic crop farmers in Norway (Koesling et al., 2004). Similarly, both conventional and organic dairy farmers assigned high importance to the strategy of preventing or reducing livestock disease as part of production risk management strategy in Norway (Flaten et al., 2005).

Disease prevention as a strategy of production management was also adopted in studies conducted on dairy farming. For instance, dairy farmers in china assigned high importance to prevent livestock disease such as foot and mouth disease (Zhou, Nanseki and Takeuchi, 2012). A study by Hayran and Gul (2015) on risk perception and management also indicated that farmers accorded high importance to disease prevention in dairy farming in Turkey. Likewise, aquaculture farmers in Norway also gave more importance to disease prevention as a mechanism of risk management strategy (Bergfjord, 2009).

Factor 2 represented the strategy of minimizing loss. These methods include selling at a low price due to perishability, producing at the lowest possible cost and sharing each other's equipment. Minimizing loss was 
perceived as an effective strategy for the smallholder vegetable producing farmers to effectively mitigate the risks related to marketing and production. Koesling et al. (2007) found the risk management strategy of low cost as important in crop farming in Norway. Aquaculture farmers in Norway also considered low cost production as an important risk management strategy. Moreover, mussel aquaculture farmers in Denmark also considered the strategy of producing at the lowest possible cost as an important risk management strategy (Ahsan and Roth, 2010).

In some cases farmers are forced to sell at low price for fear that the vegetables and fruits may perish. This strategy of selling at low price for fear of perishability of vegetables and fruits was practiced by farmers in Nigeria (Fakayode, Rahji and Adenyi, 2012). A s opposed to selling at low price, dairy farmers employed the strategy of producing at low cost. This could be attested by the findings of risk perception and management on dairy farming in Norway and Turkey (Flaten et al., 2005; Hayran and Gul, 2015).

Factor 3 represented the strategies of diversification. These include engaging in nonfarm activity, family member engaging in off farm activity, investing in nonfarm business and growing different vegetables. Income diversification was perceived as an important strategy for smallholder vegetable farmers to manage risk. Income diversification as a risk management strategy will continue to absorb more participants especially given the increasing population pressure and declining landholding size and the climate change in the agricultural sector in Eastern Ethiopia (Bezabih and Hadera, 2007).

Diversification strategy interms of engaging in nonfarm business are among the top rated risk management strategies for farmers engaging in onion production in Nigeria (Alimi and Ayanwale, 2005). Moreover, the onion farmers also engaged in crop diversification, combining onion production with some other vegetable crops. However, for rice farmers in Thailand mixed enterprise strategy and planning several varieties of crop were an important production management strategy.

Besides income diversification, growing different types of vegetables is also a means to mitigate risk in the smallholder vegetable farming system. Alimi (2005) in the case of Nigeria also considered crop diversification among the strategies used to reduce risks related to onion crop production. The other diversification strategy is geographical diversification. Farmers engaging in aquaculture farming accorded high importance to geographic diversification as a means of enhancing the sustainability of aquaculture farming (Bergfjord, 2009). Farmers considered this form of diversification to reduce production risk and contract obligation risk (Oglend and Tveteras, 2009).

Table 4. Average score and oblimin rotated factor loading for risk responses

\begin{tabular}{|c|c|c|c|c|c|c|}
\hline & \multicolumn{3}{|l|}{ Sample } & \multicolumn{3}{|c|}{ Factors } \\
\hline & Communality & Mean & SD & 1 & 2 & 3 \\
\hline Joint operation in cropping and harvesting & 0.521 & 3.04 & 1.1 & -0.25 & 0.53 & 0.431 \\
\hline Shared ownership of equipment & 0.601 & 2.83 & 1.13 & 0.273 & 0.548 & 0.155 \\
\hline Producing at lowest possible cost & 0.499 & 2.8 & 1.3 & 0.113 & 0.641 & 0.042 \\
\hline Maintain good relations with traders & 0.484 & 2.78 & 1.19 & 0.314 & 0.537 & $\overline{0}-024$ \\
\hline Selection of preferred vegetable varieties & 0.428 & 2.77 & 1.09 & 0.219 & 0.074 & 0.491 \\
\hline Growing different vegetables & 0.606 & 2.73 & 1.31 & 0.419 & -0.008 & 0.484 \\
\hline Reserving inputs & 0.585 & 2.73 & 1.24 & 0.56 & 0.025 & 0.316 \\
\hline Sell at low prices & 0.567 & 2.71 & 1.09 & $\overline{0}-197$ & 0.777 & 0.056 \\
\hline Holding cash and other assets & 0.583 & 2.7 & 1.36 & 0.523 & -0.015 & 0.38 \\
\hline Transacting via cooperative & 0.426 & 2.7 & 1.37 & 0.371 & 0.414 & 0.021 \\
\hline Use relevant information on vegetable production & 0.639 & 2.69 & 1.39 & 0.75 & 0.031 & 0.079 \\
\hline Renting/sharing motor pump & 0.411 & 2.67 & 1.08 & 0.001 & 0.396 & 0.374 \\
\hline Apply insecticide and pesticide & 0.658 & 2.66 & 1.39 & 0.735 & 0.117 & 0.058 \\
\hline Having diversified crop and/or animal enterprises & 0.685 & 2.65 & 1.42 & 0.681 & -0.114 & 0.314 \\
\hline $\begin{array}{l}\text { Use development agent's advice on vegetable } \\
\text { production }\end{array}$ & 0.637 & 2.65 & 1.25 & 0.744 & -0.061 & 0.146 \\
\hline $\begin{array}{l}\text { Increasing the labour force during preparation, } \\
\text { planting, weeding, and harvesting }\end{array}$ & 0.658 & 2.63 & 1.39 & 0.759 & 0.213 & $-\overline{0}(098$ \\
\hline Use of fertilizer & 0.727 & 2.59 & 1.48 & 0.869 & 0.059 & $\overline{-}-093$ \\
\hline $\begin{array}{l}\text { Engaging in vegetable farming using plots in } \\
\text { different location }\end{array}$ & 0.366 & 2.57 & 1.15 & 0.207 & 0.543 & 0.093 \\
\hline Working non-farm to supplement net farm income & 0.553 & 2.57 & 1.09 & 0.145 & 0.046 & 0.648 \\
\hline
\end{tabular}




\begin{tabular}{|l|l|l|l|l|l|l|}
\hline & \multicolumn{3}{l|}{ Sample } & \multicolumn{3}{l|}{ Factors } \\
\hline & Communality & Mean & SD & $\mathbf{1}$ & $\mathbf{2}$ & $\mathbf{3}$ \\
\hline Use of improved seed variety & 0.778 & 2.51 & 1.53 & 0.843 & 0.104 & - \\
& & & & & & 0.002 \\
\hline Family members working off-farm & 0.348 & 2.46 & 1.07 & - & -0.008 & 0.597 \\
& & & & 0.009 & & \\
\hline Using irrigation & 0.672 & 2.46 & 1.48 & 0.817 & 0.075 & - \\
Table 4 (continued) & & & & & & 0.058 \\
\hline $\begin{array}{l}\text { Have a farm reservoir for water supplies in the dry } \\
\text { season }\end{array}$ & 0.597 & 2.43 & 1.34 & 0.789 & -0.174 & 0.059 \\
\hline Investing in non-farm investment/business & 0.285 & 2.38 & 1.01 & 0.055 & 0.052 & 0.501 \\
\hline Using on farm storage for vegetables & 0.39 & 2.36 & 1.11 & 0.604 & 0.042 & 0.01 \\
\hline Percent of total variance explained & & & & 41.67 & 8.663 & 4.478 \\
\hline Cumulative percent of the variance explained & & & & 41.67 & 50.333 & 54.81 \\
\hline
\end{tabular}

Source: own computation

\section{Conclusion and Policy Implications}

The objective of this study was to examine the smallholder vegetable farmers' perception of risk and risk management strategies. A questionnaire survey was carried out among smallholder farmers in Eastern Hararghe zone of Oromia in Ethiopia. The major sources of risk in smallholder vegetable farming were identified to be low profitability, energy inaccessibility, production, input and output price variability, social/human \& institutional.

Identifying such sources of risks would help to better understand the nature and dynamics of risk and uncertainty in smallholder vegetable farming system. Moreover, it could help to come up with intervention designed to cope with the perceived risks. From the analysis, the majority of the respondents were found to be relatively risk-takers to various risks. This behavior of farmers points to the need to establish credit access in Eastern Ethiopia which could motivate farmers to use optimal farm input to achieve higher vegetable output. This could also have the effect of enhancing the efficiency of the vegetable producing farm enterprise thereby rendering the overall risk management strategy effective.

Farm households also face institutional and human/social related risks. Institutional risks are related to the lack of fair distribution of subsidized inputs by the cooperative or union. A form of accountability mechanism should be established to regulate the functioning of these organizations. It is also important to make the services given by these institutions to smallholder vegetable farmers efficient.

The other social problem is related to the declining farm size which is largely a cause for conflict and violence among family members. Hence, government assistance is needed in encouraging farmers to engage in intensive vegetable farming on the fragmented landholdings. However, for this to be successful, irrigation development and expansion should also be given due concern.

The availability of energy is also imperative for households living in rural areas. Energy is used for home and agricultural purpose. Energy as input is required in all stages of agricultural production like running machinery, managing water, operating irrigation and harvesting. After harvest, energy could also be used for food processing, storage and transportation.

Energy is essential for agricultural development and the main factor for achieving food security. Even though Ethiopia possesses enormous renewable energy potential, only a small fraction of the population has access to electricity. The renewable energy sources include hydro, wind, geothermal, solar as well as biomass. Hence, the government and other development partners need to harness these alternative energy sources to help rural smallholder farmers in their farming activity.

The risk of fluctuating price could be mitigated through diversification of production, supplying via cooperatives and using storage. In addition to providing training and reliable information to farmers, the government should also focus on maintaining safety nets to farmers to compensate them for income lost as a result of catastrophic events or major disturbances of the market. To ameliorate the condition of farmers, the government policy should also focus on the provision of disaster assistance, fiscal measures, storage support and facilitating the provision of credit for farmers.

Production risk management is essential for smallholder vegetable farmers to combat production-related risk like pest and termite attack. In this regard, smallholder vegetable farmers need to be assisted on accessing inputs like pesticides and insecticide to mitigate the impacts of these diseases. Moreover, smallholder vegetable farmers need also be assisted on using water harvesting technology to gain access to water during the dry season. A mechanism should also be established for the provision of timely farm information to smallholder vegetable farmers. 
In addition to the aforementioned production risk management strategies, policymakers need also focus on loss minimizing and diversification strategies. The loss minimizing strategy allows the smallholder vegetable farmers to manage marketing, production and cost-related risks. To help mitigate marketing risk, cooperatives need to operate efficiently in serving the smallholder vegetable farmers. Moreover, the diversification strategy should also be encouraged by policymakers to increase the diversification options available to the smallholder vegetable farmers. Hence, development policy should support the expansion of self-employment, wage employment and strengthen micro and small-scale enterprises in rural areas of Ethiopia.

\section{Acknowledgments}

We acknowledge the Ethiopian Ministry of Education for financing the Ph.D. study. We are also grateful for the comments provided by the anonymous reviewers.

\section{References}

Aditto, S., Gan, C. \& Nartea, G.V. A. (2012), "Sources of Risk and Risk Management Strategies: The Case of Smallholder Farmers in a Developing Economy, in Risk Management - Current Issues and Challenges", 449474.

Ahsan, D.A., \& Roth, E. (2010), "Farmers' perceived risks and risk management strategies in an emerging mussel aquaculture industry in Denmark" Marine Resource Economics 25, 309-23.

Ahsan, D. A. (2011), "Farmers' motivations, risk perceptions and risk management strategies in a developing economy: Bangladesh experience" Journal of Risk Research, 14(3), 325-349.

Ali, J. and Kapoor, S. (2008), "Farmers' Perception on Risks in Fruits and Vegetables Production: An Empirical Study of Uttar Pradesh", Agricultural Economics Research Review 21, 317-326.

Akcaoz, H., Kizilay, H. \& Ozcatalbas, O. (2009), "Risk Management Strategies in Dairy Farming”, Journal of Animal and Veterinary Advances 8, 949-958.

Alimi, T. \& Ayanwale, A. B. (2005), "Risk and Risk Management Strategies in Onion Production in Kebbi State of Nigeria", J. Soc. Sci. 10, 1-8.

Asravor, R. (2018), "Smallholder farmers' risk perceptions and risk management responses", African Journal of Economic and Management Studies, 9(3), 367-387.

Belaineh, L. \& Drake, L. (2005), "Determinants of Smallholder Farmers' Perceptions of Risk in the Eastern Highlands of Ethiopia", Journal of Risk Research, 8, 383-416.

Bergfjord, O. J. (2009), "Risk perception and risk management in Norwegian aquaculture", Journal of Risk Research 12(1), 91-104.

Emana, B. and Gebremedhin, H. (2007), "Constraints and Opportunities of Horticulture Production and Marketing in Eastern Ethiopia”, DCG Report, No.462.

Chavas, J.P. \& Holt, M. T. (2006), "Acreage Decisions under Risk: The Case of Corn and Soybeans", American Journal of Agricultural Economics 72, 529-538.

Dercon, S. (2002), "Income Risk, Coping Strategies, and Safety Nets" The World Bank Research Observer 17, 141-166.

East Hararghe Zonal Agricultural Bureau. (2017), East Hararghe Profile, Plan and Programme Department, Harar.

Ethiovisit. (2019). Ethiopia Administrative Regions, Cities and Population. Retrieved March 13, 2019, from https://www.ethiovisit.com/ethiopia/ethiopia-regions-and-cities.html.

Fakayode, S. B., Rahji, M. A.Y. \& Adeniyi, S. T. (2012), "Economic Analysis of Risks in Fruit and Vegetable Farming in Osun State, Nigeria” Bangladesh Journal of Agricultural Research, 37, 473-491.

Flaten, O., Lien, G., Koesling, M., Valle, P.S., Ebbesvik, M. (2005), “Comparing Risk Perceptions and Risk Management in Organic and Conventional Dairy Farming: Empirical Results from Norway" Livestock Production Science, 95, 11-25.

Goodwin, B and Mishra, A. (2004), "Farming efficiency and the determinants of multiple job holding by farm operators", American Journal of Agricultural Economics 86, 722-729.

Hair, J.F. (2006), "Multivariate data analysis", 6th ed. New Jersey: Pearson Prentice Hall.

Harding, R. (ed) (1998), "Environmental Decision-Making: The Roles of Scientists, Engineers and the Public”, Sydney, New South Wales, Australia: The Federation Press.

Hayran, S., and Gül, A. (2015), "Risk Perception and Management Strategies in Dairy Farming: A Case of Adana Province of Turkey", Turkish Journal of Agriculture - Food Science and Technology, 3(12), 952-961.

Kahan, D. (2013), "Managing Risk in Farming", Food and Agriculture Organization of the United Nation, Rome.

Kinfe. G. \& Tewodros, T. (2014), "Risk Perception and Management in Smallholder Dairy Farming in Tigray, Northern Ethiopia", Journal of Risk Research 17, 367-381.

Koesling, M., Ebbesvik, M., Lien, G., Flaten, O., Valle, P. \& Arntzen, H. (2007), "Risk and risk management in organic and conventional cash crop farming in Norway", Acta Agriculturae Scandinavica, Section CFood Economics 1, 195-206. 
Kumilachew, A. , Fekadu, G. \& Mengistu, K. (2014), "Risks in vegetables production from the perspective of smallholder farmers: The case of Kombolcha District, Oromia region, Ethiopia", Agriculture, Forestry and Fisheries 3, 1-5.

Maniania, N.K., Ekesi, S. and Songa, J.M. (2002), "Managing termites in maize with the entomopathogenic fungus Metarhizium anisopliae", International Journal of Tropical Insect Science 22, 41-46.

Nicol, R. M., Ortmann, G. F. and Ferrer, S. RD. (2010), "Perceptions of key business and financial risks by largescale sugarcane farmers in KwaZulu-Natal in a dynamic socio-political environment", Agrekon: Agricultural Economics Research, Policy and Practice in Southern Africa, 46(3), 351-370.

Nigussie. D., Haile, D., Wole, K., Tamiru, A., Olkeba, B., Samuel, T., Solomon, A. \& Mengistu, K. (2014). "Participatory Rural Appraisal Report: Haramaya District, Eastern Oromia Region", Haramaya: Haramaya University.

Nigussie, B.A. and Jeylan, H. W. (2017), "Challenges in Managing Land-Related Conflicts in East Hararghe Zone of Oromia Regional State, Ethiopia" Society \& Natural Resources 31, 351-366.

Oglend, A., \& Tveteras, R. (2009), "Spatial diversification in Norwegian aquaculture" Aquaculture Economics and Management, 13(2), 94-111.

Otieno, H. M. O. (2018), "Impacts and Management of Termites (Isoptera: Termitidae) among Smallholder Farmers in East Africa" Journal of Agriculture and Ecology Research International,16, 1-12.

Schnepf, R. (2004), CRS Report for Congress : Energy Use in Agriculture : Washington, D.C.

Sekamatte, B.M., Ogenga-Latigo, M. \& Russellsmith, A. (2003), "Effects of maize-legume intercrops on termite damage to maize, activity of predatory ants and maize yields in Uganda", Crop Protection 22, 87-93.

Sjoberg, L. (1998), "World views, political attitudes and risk perception", Risk: Health, Safety and Environment 9, 137-52.

Watson, J. C. (2017), "Establishing evidence for internal structure using exploratory factor analysis, Measurement and Evaluation in Counseling and Development", Taylor \& Francis 50, 232-238.

Zhou, H., Nanseki, T., \& Takeuchi, S. (2012), "Dairy Farmers' Risk Perception and Risk Management in China Evidence from Hebei Province and Inner Mongolia", Agricultural Information Research, 21(2), 20-27. 


\section{Appendix 1}

a. Scree plot: Risk Sources

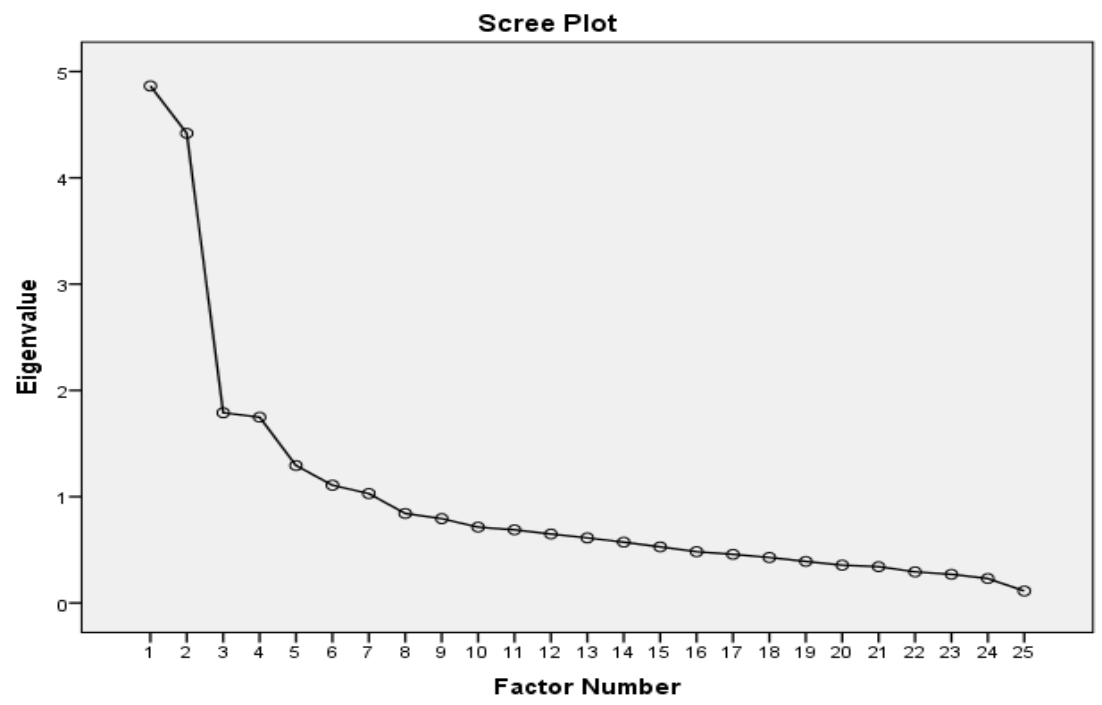

b. Scree plot: Risk management strategies

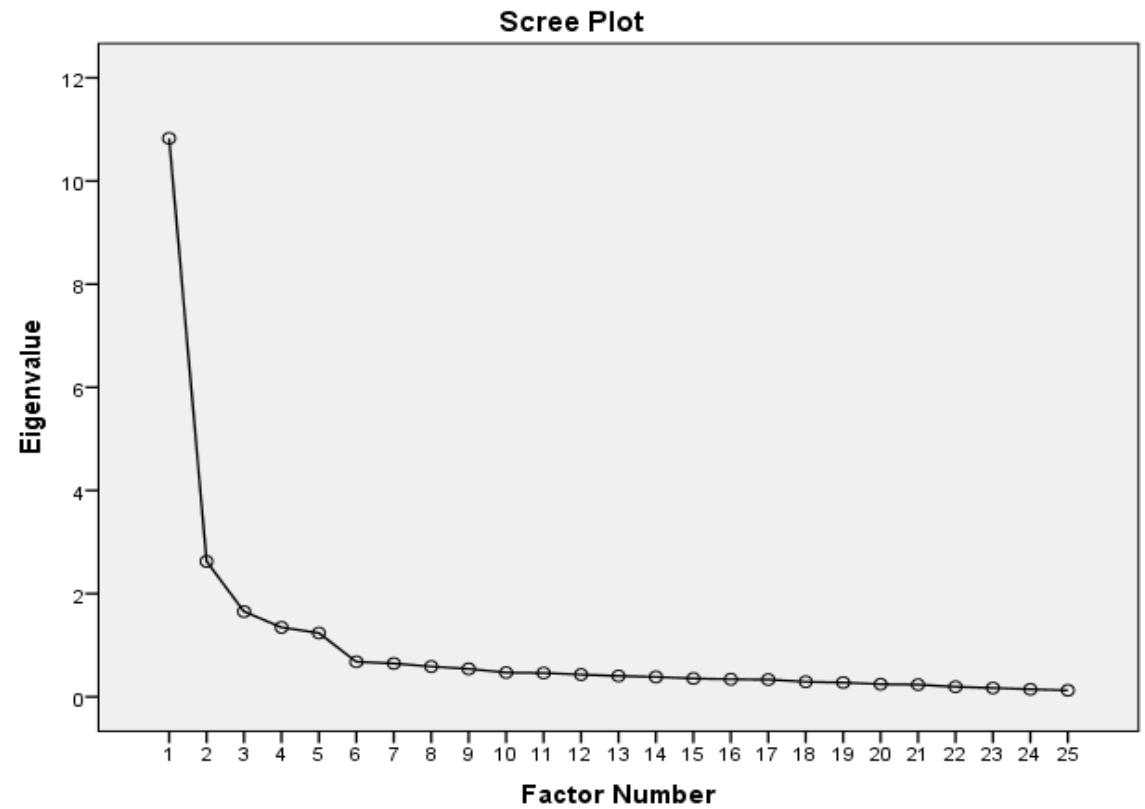

